\title{
Trade Creation, Diversion Effects and Exchange Rate Volatility in the Global Meat Trade
}

\author{
David Karemera \\ South Carolina State University, Orangeburg, USA \\ Won $\mathrm{Koo}$ \\ North Dakota State University, Fargo, USA \\ Gerald Smalls \\ Benedict College, Columbia, USA \\ Louis Whiteside \\ South Carolina State University, Orangeburg, USA
}

\begin{abstract}
A modified gravity model is specified and applied to meat trade markets to identify factors affecting bovine and swine meat trade flows. The model is used to evaluate the effects of bilateral and regional free trade agreements. This study reveals that gravity models can be effectively parameterized and used in single commodity trade studies. Using data from 1986 to 2009, the results show that income, population, production capacity, distance, and exchange rate volatility are major factors affecting meat trade.
\end{abstract}

\footnotetext{
* Corresponding Author: David Karemera; School of Business, South Carolina State University, 300 College, St NE, Orangeburg, SC 29117, USA; Tel: +803 5367136, Fax:+803 5333639, E-mail: karemera@scsu.edu.

Co-Author: Won Koo; Department of Agribusiness \& Applied Economics, North Dakota State University, Fargo, ND 58105, USA; Tel: +701 2317448, E-mail: Won.koo@ndsu.edu.

Gerald Smalls; School of Business, Benedict College, SC 29204, Columbia, USA; Tel: +803 7054448, Fax: +803 7056582, E-mail: ghubbardsmalls@hotmail.com.

Louis Whiteside; 1890 Research, South Carolina State University, Orangeburg, SC 29117, USA; Tel: +803 5368971, E-mail: whitsides1@scsu.edu.
}

Acknowledgements: The authors thank participants at the 2012 Conference: Emerging Issues in Global Animal Product Trade held in Washington DC on September 27-28, 2012. Financial support of the 1890 Research is gratefully acknowledged. 
The findings also demonstrate that the formation of the North American Free Trade Agreement and European Union significantly enhanced bovine and swine meat trade flows through trade creation among members and trade diversion from non-members to members. The Common Market of the South led to trade creation with inconclusive results for trade diversion while the Association of South-East Asian Nations led to trade diversion with no evidence of increased intra-bloc trade. The hoof-and-mouth disease significantly impaired bovine meat trade flows.

\section{JEL Classification: F13, F15, F19}

Keywords: Regional Free Trade Agreements, Trade Creation and Diversion, Exchange Rate Volatility, Bovine and Swine Meats, NAFTA, EU, ASEAN, MERCOSUR

\section{Introduction}

International trade and trade direction are normally based on the principles of comparative advantage under a free market system. However, commodity trade flows are often affected by government trade policies in both origin and destination countries, and by exchange rate volatility, among other factors.

Previous studies have evaluated the determinants of trade flows of aggregate or semiaggregate goods using gravity models. Most studies of aggregate trade flows assume that the impact of trade determinant factors is uniform across commodity trade sectors. This assumption generates problematic results because the approach ignores the possible aggregation effects and influential characteristics of individual commodities. Thus, this study adopted a disaggregated-commodity level analysis of trade flows with application to selected meats.

A commodity-specific generalized gravity model is specified and applied to selected bovine and swine meat trade flows. The aim of the study is to identify and analyze factors affecting meat trade, and discuss the impacts of regional economic integrations and exchange rate volatility on global meat trade flows.

Traditional gravity models have been revised and effectively parameterized. The model can now identify and evaluate the determinants of specific trade flows such as countries' income, distance to trading countries, Regional Free Trade Agreements 
(RFTA), exchange rate uncertainty, and other pertinent variables. Unlike previous studies that used cross section data alone, this study used panel data, allowing researchers to capture both time series and country effects and evaluate the key determinants of meat trade flows.

In addition to the evaluation of the traditional determinants of trade flows, the impacts of major RFTs were specifically examined in this study. The RFTAs were examined to evaluate trade creation and trade diversion effects on bovine and swine meat trade flows and address the intra- and inter-group trade effects. The results will reveal the extent to which major world regional economic blocs have expanded trade among members and possible impacts on non-member countries. The world's major RFTAs included in this study are the North American Free Trade Agreement (NAFTA), European Union (EU), Association of Southeast Nations (ASEAN), and Common Market of the South (MERCOSUR) which is the agreement made among a few South American nations.

It is commonly known that gravity models have been used to evaluate bilateral trade flows of aggregate commodities between pairs of countries. In this study, the models are modified to examine the determinants of meat trade flows and impacts of major regional economic integrations. The gravity model for meat trade contains the following three variable components:

(i) Economic and non-economic factors affecting meat trade flows in the source country.

(ii) Economic and non-economic factors affecting meat trade flows in the destination country.

(iii) Natural or artificial factors enhancing or impairing meat trade flows.

Traditional models incorporate these factors in cross sectional studies and ignore variation over time. A panel framework is adopted in this study while panel gravity models are applied to balanced data.

The remainder of this paper is organized as follows. Section II provides an overview of the relevant literature. Section III highlights the changing behavior of meat trade flows with focus on major meat exporting countries. Section IV presents the specification of the commodity-specific gravity model and explains the data. Section V presents the econometric issues related to the estimation of the gravity model with pooling techniques. The empirical results are presented in Section VI while the last section presents the conclusions. 


\section{Literature Review}

Formal theoretical foundations for the gravity model exist in literature. Anderson (1979) was the first to address the theory of a conventional gravity model used in Linneman (1966). Bergstrand $(1985,1989)$ provided a sound theoretical foundation of the gravity model and derived the so-called generalized gravity equations that included price variables. Anderson and van Wincoop (2003) produced a derivation of gravity models that included trade resisting factors for proper specification and empirical inferences. Helpam et al. (2008) developed an expanded version of the Anderson and van Cooper (2003) model to account for the heterogeneity of exporting firms and produced a generalized gravity model of international trade that can be used to address the impacts of trade-resisting factors on the volume of trade.

The empirical success of the gravity models is now widely acknowledged. For example, Bacchetta and van Wincoop (2000), Cho, Sheldon, and McCorriston (2002), and Hilbun (2006), among others, used aggregate or semi-aggregate trade flows. Koo, Karemera, and Taylor (1993) and Karemera et al. (2009) are among the few exceptions that applied gravity models on specific commodity trade flows to address the policy implications of free trade. Egger (2004) and Martinez et al. (2008) used gravity models to estimate the impacts of regional free trade blocs on trade flows. However, few studies including Koo, Karemera, and Taylor (1993); Cao and Johnson (2006); Dascal, Mattas, and Tzouvelekas (2002); Jayasinghe and Sarker (2008) focused on meat trade. This study provides further insights on impacts of major free trade agreements on bovine and swine meat trade flows.

\section{World's Major Bovine and Swine Meat Exporters}

\section{A. Bovine meat trade}

\section{Australia}

Australia is the world's largest beef exporter. Because of increasing world population and economic growth, the North Australian corporations continue to assist beef 
production and exports. The South Australian disparate and fragmented production is expected to increase in volume. Several different businesses are involved in raising the many different breeds of cattle among the many varied climates and pasturelands of Australia. Australian beef, exported mostly to Japan, Korea, and the United States, has its quality judged by the amount of marbling in it. Because of its small population, Australia must export majority of its beef. It takes advantage of its wide open pasturelands and has installed a system to guarantee that its cattle have no disease. However, from Table 1 we see that Australia has steadily lost its market share of beef except during the year 2004 when the United States suffered a setback due to Mad Cow disease.

\section{Brazil}

Brazil wants to be the world's largest exporter of beef. To improve the quality and quantity of their beef, farmers are learning many new cattle ranching practices. They also continuously improve the management of their pastures and perform genetic analysis for breeding purposes. Brazil steadily increased its market share of beef until 2007.

\section{The Netherlands}

In the Netherlands, small companies produce more than $80 \%$ of bovine meat. The practice led to the formation of cooperative groups and other joint marketing organizations. From Table 1, we see that the Netherlands consistently increased its market share through the year 2009.

\section{The United States}

In the United States, a major environmental concern is about nitrous oxide, which has 296 times the warming effect of carbon dioxide. The US confines the cattle to feed on grain. The amount of nitrous oxide produced could be reduced by performing better farm practices. In the future, environmentally friendly practices will be the worldwide norm for producing healthy, high-quality beef. The United States does need to focus on environmental safety in order to regain the beef market share that it lost in 2004 due to the outbreak of Mad Cow disease.

\section{Germany}

Germany continues to have many ways of organizing its food chain. However, it appears to be in transition from a buyer's market to a more cooperative market. 
Competition among the few large retailing businesses has led to private labels, which function as national brands. This competition among retailers has also led to cooperation with their suppliers to reduce the costs of buying and selling. Germany has increased its market share slightly since the year 2000 .

\section{France}

Unlike Australia, France consumes most of the beef it produces. However, like Australia, France has cultivated many different breeds of cattle and has many different types of landscapes, climates, and pasturelands. The production of high quality beef is a priority for French beef producers. France has attained a nearly constant market share level.

\section{Denmark}

Table 1 shows that Denmark has less than $2 \%$ of the market share of beef. The country, however, was the seventh largest bovine meat exporter during the period of study.

Table 1. Bovine meat-exporting countries' export shares

\begin{tabular}{|c|c|c|c|c|c|c|c|c|c|c|}
\hline & \multicolumn{70}{|c|}{ Year } \\
\hline Country & 2000 & 2001 & 2002 & 2003 & 2004 & 2005 & 2006 & 2007 & 2008 & 2009 \\
\hline Australia & $15.1 \%$ & $19.0 \%$ & $16.3 \%$ & $14.6 \%$ & $19.2 \%$ & $17.7 \%$ & $16.2 \%$ & $15.2 \%$ & $14.7 \%$ & $13.2 \%$ \\
\hline Brazil & $5.4 \%$ & $7.7 \%$ & $7.8 \%$ & $8.8 \%$ & $12.2 \%$ & $13.5 \%$ & $15.0 \%$ & $15.0 \%$ & $12.7 \%$ & $11.2 \%$ \\
\hline Netherlands & $7.8 \%$ & $6.1 \%$ & $7.7 \%$ & $9.3 \%$ & $9.5 \%$ & $9.7 \%$ & $9.7 \%$ & $10.0 \%$ & $10.2 \%$ & $10.8 \%$ \\
\hline US & $23.3 \%$ & $21.9 \%$ & $19.1 \%$ & $19.4 \%$ & $3.0 \%$ & $4.3 \%$ & $6.4 \%$ & $7.8 \%$ & $9.1 \%$ & $9.2 \%$ \\
\hline Germany & $6.1 \%$ & $7.1 \%$ & $7.3 \%$ & $7.2 \%$ & $7.8 \%$ & $6.8 \%$ & $7.4 \%$ & $7.3 \%$ & $8.0 \%$ & $8.3 \%$ \\
\hline France & $5.6 \%$ & $3.3 \%$ & $4.7 \%$ & $5.7 \%$ & $5.4 \%$ & $5.0 \%$ & $5.1 \%$ & $5.1 \%$ & $5.2 \%$ & $5.3 \%$ \\
\hline Denmark & $2.1 \%$ & $1.8 \%$ & $1.9 \%$ & $1.7 \%$ & $1.9 \%$ & $1.8 \%$ & $1.6 \%$ & $1.6 \%$ & $1.6 \%$ & $1.8 \%$ \\
\hline Total & $\mathbf{6 5 . 4 \%}$ & $\mathbf{6 6 . 9} \%$ & $\mathbf{6 4 . 9 \%}$ & $\mathbf{6 6 . 5} \%$ & $\mathbf{5 9 . 1 \%}$ & $\mathbf{5 8 . 8} \%$ & $\mathbf{6 1 . 4 \%}$ & $\mathbf{6 2 . 0 \%}$ & $\mathbf{6 1 . 3 \%}$ & $\mathbf{5 9 . 7 \%}$ \\
\hline
\end{tabular}




\section{Figure 1. Major beef exporting countries ${ }^{1}$}

(Measurement Unit: kg)

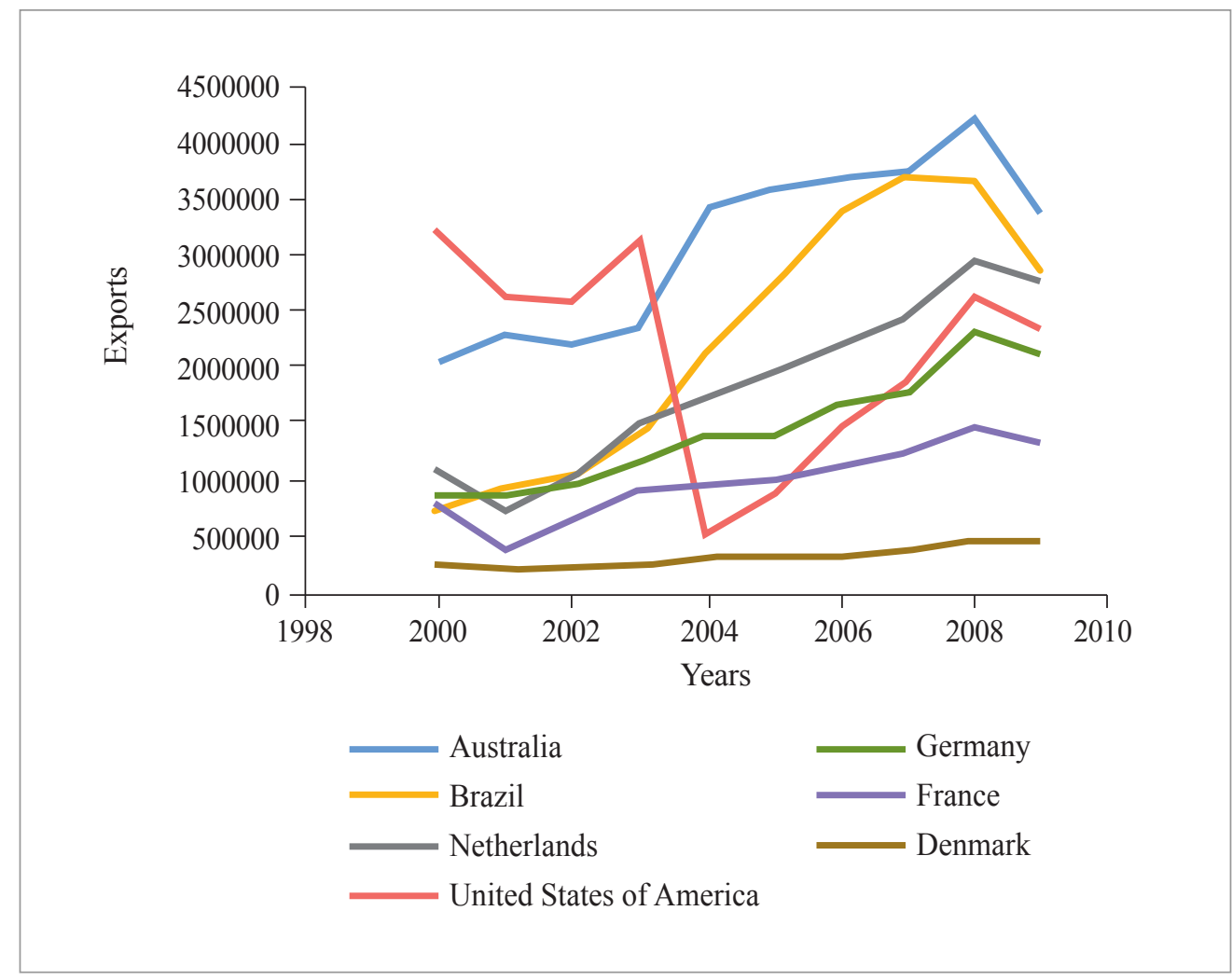

\section{B. Swine meat trade}

\section{Denmark}

Denmark's sophisticated and highly concentrated pig industry includes breeding material, extension services, training of farmers, housing of pigs, feeding of pigs, meat processing companies, production of processing equipment, and production technology.

As a comparison, this statement provides a brief review of the bovine meat market behavior in China. Beef is popular in restaurants and homes in China, the world's second largest economy and most populous nation. However, its domestic beef consumption is significantly lower than its consumption of pork. Indeed, according to data from Food and Agriculture Organization (FAOSTAT) (2010), beef consumption increased by $15.2 \%$ from 2000 to 2005 in its urban area while from 2005 to 2010 , its urban rate of increase was reduced to $11 \%$. China is ranked $14^{\text {th }}$ in bovine meat exports. Given that China's per capita income is increasing at a decreasing rate, the authors expect that the amount of increase in beef consumption, imports, and exports will remain relatively unchanged. In the near future, China's primary trading partner in beef is expected to remain Australia (Zhou 2012). 
The country leads the swine export market. However, from Table 2, we see that Denmark's market share among the top seven pork exporters has dropped from about $33.5 \%$ in 2001 to $21.4 \%$ in 2009 . Denmark sees itself in business to supply the highest quality of pork meat to the world. Each pig marketed must be fully traceable from the farm to slaughterhouse. Danish has become a strong brand name for their exports. Denmark can expand its pig industry using land in its neighboring countries and maintain high Danish quality.

\section{The United States}

Together, Iowa and North Carolina show $43.1 \%$ of the United States hog inventory, making both states the largest US pork producers during the study period of 2000 through 2009. Iowa, North Carolina, Minnesota, and Illinois provided over $61 \%$ of the hog inventory. Table 2 shows that the pork market share of the US is among the top seven exporters and fluctuated between $17.4 \%$ and $24.5 \%$.

\section{Germany}

Germany will continue to have many ways of organizing its food chain. However, it appears to be in transition from a buyer's market to a more cooperative market. Competition among the few large retailers has led to private labels, which function as national brands. This competition among the retailers has also led to cooperation with their suppliers to reduce the costs and increase its market share.

\section{The Netherlands}

In the Netherlands, small companies also produce more than $80 \%$ of swine meat. As in the above meat case, the competitive production system has led to the formation of cooperative groups and other marketing organizations. From Table 2, we see that competition has caused its market share of exports to drop over the years from 2000 to 2009.

\section{Belgium}

Table 2 shows that Belgium has a small market share of pork exports. The shares remain low because their meat processing and distributing industries have abused their purchasing power. 


\section{Spain}

Spain has only a small proportion of the market share of pork exports. However, the country's swine market share has been increasing since Spain joined the European Union (EU).

\section{France}

France also has a relatively small market share of pork exports. This has been blamed on excessive increase in feed prices which could not be passed on to the consumer.

Table 2. Swine meat exporting countries' export shares

\begin{tabular}{|c|c|c|c|c|c|c|c|c|c|c|}
\hline & \multicolumn{10}{|c|}{ Year } \\
\hline Country & 2000 & 2001 & 2002 & 2003 & 2004 & 2005 & 2006 & 2007 & 2008 & 2009 \\
\hline Denmark & $31.9 \%$ & $33.5 \%$ & $32.2 \%$ & $31.3 \%$ & $28.6 \%$ & $26.2 \%$ & $27.2 \%$ & $26.0 \%$ & $22.3 \%$ & $21.4 \%$ \\
\hline US & $17.8 \%$ & $16.0 \%$ & $15.9 \%$ & $14.0 \%$ & $14.9 \%$ & $17.1 \%$ & $16.6 \%$ & $16.8 \%$ & $20.1 \%$ & $19.8 \%$ \\
\hline Germany & $3.1 \%$ & $5.3 \%$ & $6.1 \%$ & $6.6 \%$ & $7.5 \%$ & $8.9 \%$ & $10.7 \%$ & $11.5 \%$ & $12.5 \%$ & $14.6 \%$ \\
\hline Netherlands & $9.9 \%$ & $8.4 \%$ & $7.6 \%$ & $9.6 \%$ & $9.7 \%$ & $8.4 \%$ & $7.7 \%$ & $7.9 \%$ & $7.2 \%$ & $7.3 \%$ \\
\hline Belgium & $7.7 \%$ & $8.8 \%$ & $8.1 \%$ & $7.3 \%$ & $7.4 \%$ & $6.7 \%$ & $6.6 \%$ & $6.8 \%$ & $6.9 \%$ & $7.2 \%$ \\
\hline Spain & $4.8 \%$ & $4.6 \%$ & $4.8 \%$ & $5.5 \%$ & $6.0 \%$ & $6.6 \%$ & $6.6 \%$ & $7.6 \%$ & $8.0 \%$ & $7.9 \%$ \\
\hline France & $7.2 \%$ & $6.8 \%$ & $6.5 \%$ & $6.3 \%$ & $6.2 \%$ & $5.7 \%$ & $5.4 \%$ & $5.2 \%$ & $5.1 \%$ & $4.9 \%$ \\
\hline Total & $\mathbf{8 2 . 3} \%$ & $\mathbf{8 3 . 4 \%}$ & $\mathbf{8 1 . 3 \%}$ & $\mathbf{8 0 . 5 \%}$ & $\mathbf{8 0 . 4 \%}$ & $\mathbf{7 9 . 5 \%}$ & $\mathbf{8 0 . 8 \%}$ & $\mathbf{8 1 . 6 \%}$ & $\mathbf{8 2 . 0 \%}$ & $\mathbf{8 3 . 1 \%}$ \\
\hline
\end{tabular}




\section{Figure 2. Major swine meat exporting countries ${ }^{2}$}

(Measurement Unit: kg)

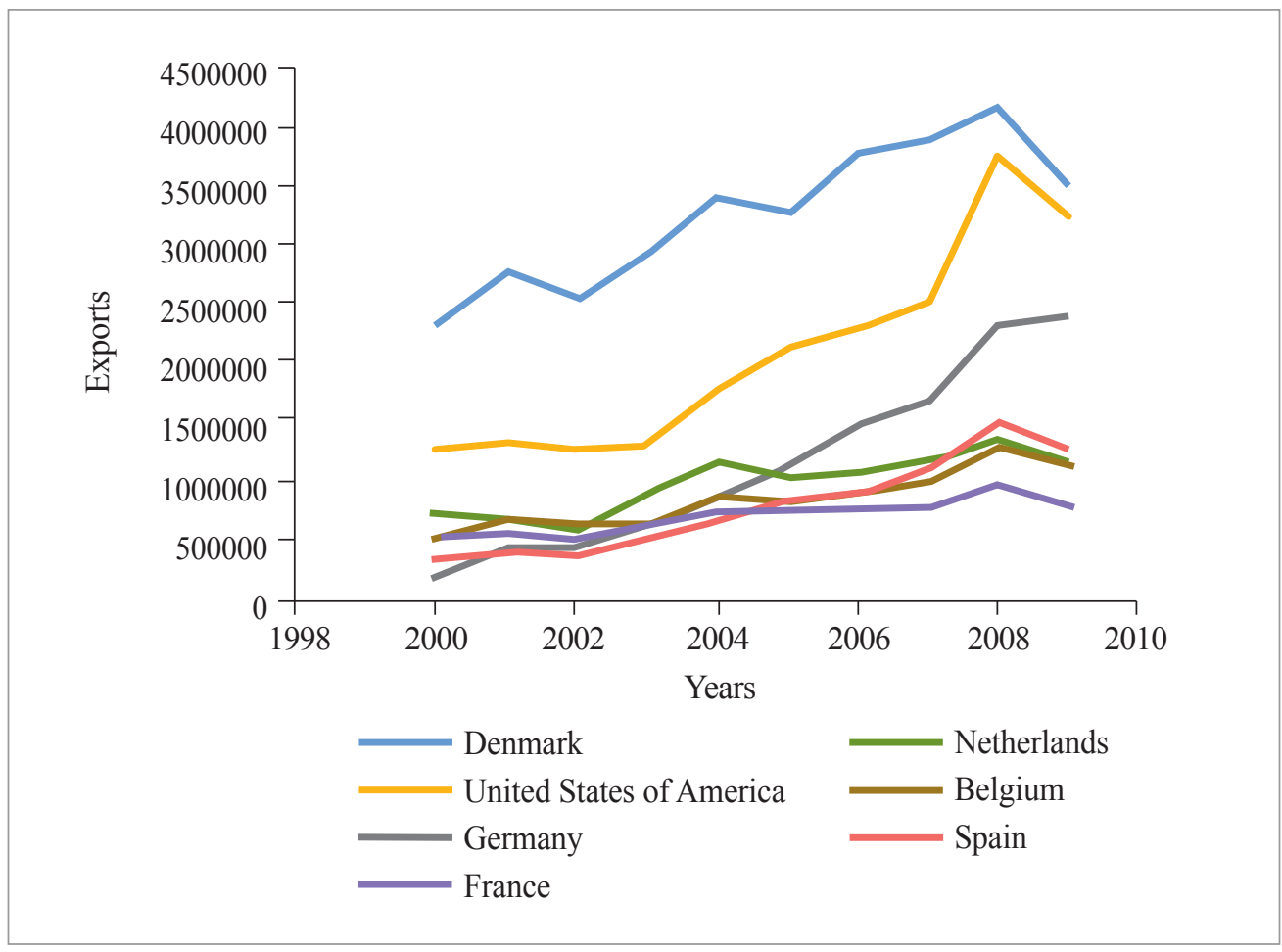

\section{Methodology}

\section{A. Commodity-specific gravity model}

This section provides a summary of the theoretical foundation of gravity models. The specification of a single-commodity gravity model follows the procedure indicated

\footnotetext{
${ }^{2}$ Swine consumption in China shows significant fluctuations over the last ten years. For example, from 2000 to 2010, on the average, Chinese people increased their consumption of pork. Pork consumption increased by $20.4 \%$ in the urban area from 2000 to 2005 ; however, from 2005 to 2010 , the rate of increase was only $2.9 \%$. The decreasing rate which was significant over the last period indicated fluctuations in consumption, caused mostly by variations in pork prices and widespread pig diseases. Nonetheless, pork consumption accounted for most of the meat consumption throughout China. According to Zhou (2012), half of the world's total swine production was produced domestically in China. Therefore, the authors believe that any pork imports are not likely to influence China's pork import market because China is expected to remain the world's top swine livestock producer in the near future.
} 
in the trade literature. According to Linneman (1966), Anderson, (1979), Bergstrand (1985, 1989), and Anderson and van Wincoop (2003), a gravity model is a reduced form of equation from a general equilibrium model of demand and supply systems. The demand model for a specific commodity is derived by maximizing the Constant Elasticity of Substitution (CES) utility function subject to income constraints. The supply model is derived from the firms' profit maximization procedure in exporting countries, with the resource allocation determined by the constant elasticity of transformation. The commodity-specific gravity model was specified under the market equilibrium condition in which demand for a commodity equals supply of the commodity. Complete theoretical derivations of the gravity equation are available in Bergstrand (1985) with additional details in Bergstrand (1989), Koo et al. (1991, 1993), and Karemera et al. (2009a; 2009b) offering applications of single-commodity gravity models.

\section{B. Specification of a generalized commodity-specific gravity model}

The traditional gravity model was re-specified to analyze the effects of factors affecting global meat trade. In addition to trade factors common to the gravity model, the model in this study was augmented with variables representing regional free trade agreements and exchange rate volatility. Additional pertinent factor includes the countries' level of development, represented by the countries' per capita Gross Domestic Product (GDP) or per capita GDP. The countries' level of development should have a positive impact on trade because there is more trade among countries with high per capita incomes as demonstrated by Pagoulatos and Sorensen (1975).

The distance between countries ( $D i j)$ was included under the hypothesis that countries close to each other are more likely to have similar cultures or cultural heritages, similar patterns of consumption and production, and high incentives for trade with each other. A relatively short distance between trading countries will enhance trade more than a relatively long distance between the countries. The dummy variable indicating countries with a common border was retained in the empirical model because, in addition to characteristics identified for countries with close proximity, it was assumed that there is more trade between countries with common borders than countries without common borders.

Since agricultural exports are a small portion of a country's GDP, the country's livestock production and population were used to represent the exporting country's 
capacity to produce and export the selected meats. GDP for the importing country was used to represent its internal market size and purchasing power. Population in the importing country represents its absorption capacity and market size.

The major regional free trade blocs in the world considered are listed in Table 6. These trade blocs are engaged in cooperative or free trade arrangements. Dummy variables representing trade flows among members were included in the model to address the extent of trade creation among members. For example, a dummy variable, NAFTA $_{\mathrm{m}}$, representing trade between two NAFTA countries, was included to evaluate NAFTA's trade creation effects. Another dummy variable, NAFTA ${ }_{n}$, representing trade between a NAFTA country and a non-NAFTA country, was used to identify the extent of trade diversion within NAFTA countries. Similarly, a dummy variable representing membership in the European Union, $\mathrm{EU}_{\mathrm{m}}$, was included to identify the extent to which membership in the EU led to the trade creation among EU members. Another dummy variable, $\mathrm{EU}_{\mathrm{n}}$, representing flows between EU and non-EU members, was included to address the extent of trade diversion in the EU. Similarly, the following additional dummy variables, ASEAN $_{\mathrm{m}}$ and $\mathrm{MERCOSUR}_{\mathrm{m}}$, represent trade creation while $\mathrm{ASEAN}_{\mathrm{n}}$ and MERCOSUR $_{n}$, represent trade diversion. It was hypothesized that economic integration under free trade arrangements enhances trade flows among member countries of a trading bloc through trade creation, whereas trade between a member and nonmember country yields trade diversion.

Following Bergstrand (1985, 1989), Anderson and van Wincoop (2003), and Karemera et al. (2009a, 2009b), an empirical model was developed on the basis of a reduced form specification. Thus, the empirical commodity-specific gravity model of meat trade was specified as follows:

$$
\begin{aligned}
& X_{i j}=B^{\beta 1}{ }_{i} Y_{j}^{\beta 2} D_{i j}^{\beta 3} N_{i}^{\beta 4} N_{j}^{\beta 5} \operatorname{Pr}_{i}^{\beta 6} \operatorname{Pr}_{j}^{\beta 7} V_{i j}^{\beta 8} \exp \left[\beta_{9} A_{i j}+\beta_{10} \operatorname{NAFTA}_{m}+\beta_{11} \operatorname{NAFTA}_{n}\right. \\
& +\beta_{12} E U_{m}+\beta_{13} E_{n}+\beta_{14} A S E A N_{m}+\beta_{15} A S E A N_{n}+\beta_{16} \operatorname{MERCOSUR}_{m} \\
& \left.+\beta_{17} \operatorname{MERCOSUR}_{n}+\beta_{18} \operatorname{HMD}_{i}\right] \quad i=1, N_{1} \text { and } j=1, N_{2}
\end{aligned}
$$

where

$X_{i j}=$ the volume of country $i$ 's export of a commodity to country $j ; Y_{i}$ $Y_{i}\left(Y_{j}\right)=$ per capita Gross Domestic Product of country $i$ (country $j$ )

$D_{i j}=$ the shortest distance between country $i$ 's commercial centers and country j's import port 
$N_{i}\left(N_{j}\right)=$ the population of exporting country $i$ (importing country $j$ )

$\operatorname{Pr}_{i}\left(\operatorname{Pr}_{j}\right)=$ per capita production in country $i$ (country $j$ )

$A_{i j}=$ the border dummy. $A_{i j}=1$ if countries $i$ and $j$ share a common border; 0 otherwise;

$V_{i j}=$ the exchange rate volatility. It is computed alternatively as short and long term volatility; and

$\varepsilon_{i j}=$ an error term.

The dummy variables NAFTA, EU, ASEAN, and MERCOSUR represent respective regional trading blocs of which subscript $m$ indicates trade among member countries of each trading blocs (trade creation) and subscript $n$ indicates trade between member countries of each trading bloc and non-member country (trade diversion).

$N A F T A_{m}=1.0$ for trade flows between NAFTA countries; 0 otherwise;

$\operatorname{NAFTA}_{n}=1.0$ for a trade flow between a NAFTA country and a non-NAFTA country; 0 otherwise;

$E U_{m}=1.0$ for trade flows between EU countries; 0 otherwise;

$E U_{n}=1.0$ for trade flows between an EU country and a non-EU country; 0 otherwise ;

$A S E A N_{m}=1.0$ for trade flows between ASEAN countries; 0 otherwise;

$A S E A N_{n}=1.0$ for a trade flow between an ASEAN member and a non- ASEAN member; 0 otherwise;

$M E R C O S U R_{m}=1.0$ for trade flows between MERCOSUR countries; 0 otherwise; $M E R C O S U R_{n}=1.0$ for trade flows between a MERCOSUR country and nonMERCOSUR countries; 0 otherwise.

Commodity specific dummy variable:

$H M D=$ hoof-and-mouth disease dummy variable: 1.0 for country recording cases of the disease and 0 for country free from the disease.

Country dummy variables: Dummy variables representing major exporting meat countries such as Australia, Brazil, France, Germany, the Netherlands, and the US were included to identify quality differentiation by origin.

Traditional gravity models typically use GDP to represent income (Linneman 
1966, Bergstrand 1985, 1989, Koo \& Karemera 1993, Karemera et al. 1999). Since bovine and swine meats are essentially staple commodities, we used per capita GDP to represent the level of development for the exporting country and the purchasing power for the importing country (Karemera 2009). Thus, a rise in the exporting country's per capita GDP may reflect an increased ability to export the commodity which would lead to increased trade flows under the assumption of increased capital/labor ratio. Consequently, the estimated coefficient of the exporting country's per capita income would be positive. However, in a single commodity trade, a rise in per capita GDP of the exporting country may also induce resources to be reallocated to a tradable good with a higher profit margin, which would lead to decreased exports of the particular commodity that has a lower profit margin. Thus, a negative coefficient would be expected (Bergstrand 1985, 1989). A rise in income in the importing country, which represents an increase in its purchasing power, leads to unambiguously higher imports and the expected coefficient sign being positive.

A country's production of a commodity was included to reflect a country's ability to supply the commodity. A rise in the exporting country's production would lead to increased exports, and a positive sign is hypothesized. A rise in the domestic production level in the importing country would be associated with reduced imports of the commodity and the coefficient is expected to be negative. Population in an exporting country reflects the country's ability to produce and export labor-intensive commodities. An increase in an exporting country's population should lead to increased production and export capacity and the coefficient is expected to be positive. The population of an importing country is an indicator of the domestic market size and large absorption capacity. Thus, an increase in the importing country population reflects increase in the importing country's domestic consumption and the coefficient is expected to be positive.

The impact of regional trade agreements was analyzed. Regional free trade variables were identified and included in the gravity models. Trade blocs and member countries are shown in Table 6. The regional free trade variables such as $\mathrm{NAFTA}_{\mathrm{m}}$, $\mathrm{EU}_{\mathrm{m}}, \mathrm{ASEAN}_{\mathrm{m}}$, and MERCOSUR $\mathrm{m}$ represent trade flows among members and thereby generate a trade creation. The signs of these variables were hypothesized to be positive.

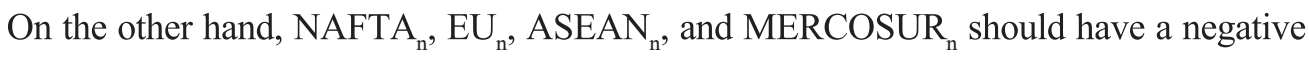
sign and represent trade diversion.

The distance variable, $d_{i j}$, was used as a proxy for transportation costs and represented resistance to trade. A negative coefficient sign was expected. The adjacency dummy variable was retained in the empirical model since it was assumed that there is even more 
trade between countries with common borders than those that are geographically farther apart.

Finally, a measure representing the exchange rate volatility was added to the empirical specification. The impact of exchange rate volatility on meat trade flows is an empirical issue. Two measures of the exchange rate volatility were proposed to address the short- and long-term impacts of the exchange rate uncertainty on meat trade flows.

\section{The impact of exchange rate volatility}

The exchange rate is one of the macroeconomic factors affecting international trade flows and is also one of the most researched topics. However, the effects of the exchange rate volatility, or the impacts of uncertainty arising from exchange rate changes on trade flows remain controversial. The empirical findings are still inconclusive at best. Most of the previous empirical studies use aggregate commodity trade flows and, as such, assume that the effect of exchange rate volatility is the same across commodities. Thus, ambiguity may arise, from the use of aggregate commodity trade flows and the aggregation effects that crowd out impacts on specific commodity trade flows. This shortcoming was examined in this study.

The exchange rate uncertainty is expected to influence the level of trade flows between trade partners. Risk-averse traders would reduce trade flows under increased level of uncertainty, thereby resulting in a negative impact of exchange rate uncertainty on trade flows. However, DeGrauwe and Skudelny (2000) and Bacchetta and van Wincoop (2000) suggest that under certain regularity conditions, exchange rate uncertainty may lead to increased trade flows.

The treatment of exchange rate volatility has followed the standard hypothesis that unpredictable changes in exchange rate affect trade flows negatively. However, Pick (1990) has argued that changes in exchange rate do not significantly affect agricultural trade flows for developed markets, while they negatively affect the United States exports to developing markets. Langley et al. (2000) showed that exchange rate variability positively affects poultry exports to Thailand while Cho et al. (2002), in a sectorial analysis, suggested that exchange rate uncertainty negatively affect trade flows.

This study offered two measures of both short- and long-run volatilities of exchange rates used in the literature. The first measure of volatility was computed as a moving standard deviation, following Koray and Lastrapes (1989) and Chowdhury (1993). The 
short-run volatility, $V_{t}$, is measured as:

$$
V_{t}=\left((1 / m)\left(\sum\left(\log \left(X_{t+i-1}\right)-\log \left(X_{t+i-2}\right)\right)^{2}\right)^{1 / 2}\right.
$$

Here, $X_{t}$ is the real exchange rate at time $t, m$ is the order of the moving average, and $i$ is the index summed over 1 to $m$.

Another measure of exchange rate variability accounts for the effects of exchange rate uncertainty over the long-term horizon to measure risk. Thus, following Peree and Steinherr (1989) and Cho et al. (2002), the long-run volatility of exchange rate between any two trading countries is computed as:

$$
X_{t}=\left(\left(\operatorname{Max}\left(X_{t-k}^{t}\right) / \operatorname{Min}\left(X_{t-k}^{t}\right)-1\right)+\left(1+a b s\left(X^{t}-X_{p}^{t}\right) / X_{p}^{t}\right)\right.
$$

Here, $\operatorname{Max}\left(X_{t-k}^{t}\right)$ and $\operatorname{Min}\left(X_{t-k}^{t}\right)$, respectively, represent the maximum and minimum values of the exchange rate within a moving time interval, indexed by $(t-k)$ to $t$. The function $a b s$ is the absolute value function. $X^{t}$ is the exchange rate at time $t . X_{p}^{t}$, an equilibrium exchange rate, is defined to be the average over the current moving average interval. Peree and Steinherr (1989) assumed that the first term in Equation (2) reflects the learned experience of the previous period while the second term represents a correction factor based on current exchange rate deviation from expected equilibrium levels. Cho et al. (2002) noted that the equilibrium exchange rate is traditionally set to the average rate over the previous period. The value of $k$ has been set to 4 due to a shorter time series. ${ }^{3}$ The equilibrium exchange rate was set to the average exchange rate over the moving window to be consistent with the sampled period.

\footnotetext{
${ }^{3}$ Several measures of exchange rate uncertainty exist in literature. However, there is no formula for the selection of a specific measure. Therefore, our choice of the exchange rate uncertainty measures reflects data availability, time period of study, and similarity with previous studies. The results are robust to the choice of the parameters, $m$ and $k$, in the moving process of the volatility measures (Cho et al. 2002). Alternative higher frequency exchange rates are considered but offer similar results to those from the yearly series that is reported in Tables 3 and 4.
} 


\section{Econometric Issues and Data}

\section{A. Econometric issues}

For a proper empirical investigation of trade flows and a test of the Model (1), we used a panel dataset of world countries. The time period is from 1986 to 2009 for bovine meat trade flows and from 1986 to 2007 for swine meat. Countries included in the dataset are shown in Table 5. Panel data combine time series and cross-section observations on trade flows and allow for increase in the degree of freedom. In this study, the time series is short relative to the number of estimable parameters so that traditional pooling techniques could not be properly used to estimate time effects and individual effects inherent to pooling techniques. Judge, Griffiths, Hill, Lutkepohl, and Lee (1985) offered techniques to solve the problems. Hausman (1978), Judge et al. (1985), and Hsiao (1986) also extensively discussed technical problems associated with the estimation of a model with panel data. To address the heteroskedacity problems associated with the cross section series, the model was estimated by use of the Eicher-White Heteroskedacity consistent estimator outlined in Estima Inc. (2009). ${ }^{4}$

\section{B. Data}

Countries included in the analysis are listed in Table 5 for bovine and swine meat trading countries. Meat data are from the Food and Agriculture Organization (FAOSTAT) in various issues. Comparisons of bovine and swine export markets shares for major exporting countries are shown in Tables 1 and 2. Financial data are from the International Financial Statistics of International Monetary Fund (World Economic Outlook Database) in various issues. Since ocean freight rates were not readily available, we used distance as a proxy for transportation costs. Distances between pairs of trading countries were computed using a map published by Time Atlas of Ocean (Time Book Limited).

\footnotetext{
${ }^{4}$ See Bergstrand $(1985,1989)$ for more applications of the estimation procedure.
} 


\section{Empirical Results}

We developed a gravity model that includes major regional free trade agreements to examine the determinants of global meat trade. The parameters of the model were estimated by the use of the RATS Program provided by Estima Inc. (2009). The EicherWhite Heteroskedacity consistent estimator was applied to estimate the model.

Tables 3 and 4 present the estimated parameters of the logarithmic transformation of the gravity model in Equation (1). Most of the estimated parameters had the expected signs and were statistically significant. These results are similar to those of previous studies that used gravity models to analyze aggregate trade flows. The use of commodity specific data offer more insights on the trade behavior of individual commodities in the framework of global trade. The estimated impact of specific determinants of global meat trade flows are succinctly discussed below.

\section{A. The effects of income, production, and population}

The estimated coefficients of income, population, and production have the expected signs and are significant at the 5\% level in most cases. Income in exporting country is an indication of the production capacity and ability to supply the product. Income in the receiving country is an indication of purchasing power and absorption capacity. With respect to the estimated coefficients of income, the results suggest that a rise in the income of the exporting or the importing country leads to increased trade flows of bovine and swine meats. The coefficients are positive and significant at the $1 \%$ level.

The country's production capacity variables have expected signs and are significant at the $1 \%$ level in the bovine meat exporting country and insignificant in the importing country. The estimated elasticities are less than unity, suggesting that meat trade flows are not sensitive to production capacity in the trading countries. The insensitivity to domestic production capacity in the exporting country may be due to its excess production capacity and domestic export policies and programs. In the swine model for the exporting country, the estimated elasticities have expected signs and are significant at the $1 \%$ level. However, the significance of the coefficients for the swine model in the importing country varies with model specification.

The results show that the population of trading countries is a significant factor 
enhancing trade flows. Population represents labor force and/or an indication of the production capacity of labor-intensive goods for the exporting country, as well as the size of the domestic market and absorption capacity for the importing country. The findings show that an increase in the exporting and importing country's population will lead to increased production and domestic consumption needs, respectively, thereby increasing the volume of trade.

\section{B. Trade creation and diversion effects}

Our gravity model includes variables representing factors aiding or resisting trade flows. To identify the trade creation effect of economic integration, dummy variables representing trade activities between the two member countries of each trading bloc NAFTA $_{\mathrm{m}}, \mathrm{EU}_{\mathrm{m}}, \mathrm{ASEAN}_{\mathrm{m}}$, and MERCOSUR $\mathrm{m}$ ) are included in the model as shown in Equation (1). Tables 3 and 4 present the estimated gravity model with the four major trading blocs mentioned above.

All coefficients on the free trade agreements are positive and significant at the $1 \%$ level in most cases. The findings show that NAFTA and EU led to significant trade creation as shown by positive and significant coefficient signs. The magnitude and significance of the coefficients suggest strong benefits from meat trade to association members. The results suggest that MERCOSUR association achieved strong trade creation effects while the results for the ASEAN association are inclusive.

The extent of trade diversion was also analyzed. The dummy variables $\mathrm{NAFTA}_{\mathrm{n}}, \mathrm{EU}_{\mathrm{n}}$, ASEAN $_{n}$, and MERCOSUR $n$ were included to identify trade flows between members of each trading bloc and non-members. Negative coefficients represent trade diversion of the economic integrations. A trade diversion effect arising from an economic integration occurs when trade flows are diverted from a non-beneficiary country to member countries. The findings suggest that both NAFTA and EU significantly enhanced meat trade diversion from non-members to NAFTA/EU countries. The magnitude and significance of elasticities suggested that the amount of trade creation is much greater than that of trade diversion for both associations. The MERCOSUR association shows no trade diversion while the findings suggest that the ASEAN association led to a trade diversion from non-members to members. 


\section{The effects of distance and border}

Traditional gravity model include distance and adjacency dummy variable. The theory of spatial equilibrium suggests that the quantity of commodity trade varies inversely with distance. The estimated coefficients of distance are negative and statistically significant at $1 \%$ in all cases, suggesting that distance impairs global meat trade. The estimated coefficients for border dummy variables are positive and significant at $1 \%$ level in models, suggesting increased trade volume for countries with common borders.

\section{The impacts of exchange rate volatility on meat trade flows}

The impact of the exchange rate volatility was estimated following Chowdhury (1993) and Karemera et al. (2009a, 2009b). Two different measures of exchange rate volatility were used. Tables 3 and 4 also present the results for both short and longterm volatility. The findings indicate that the short-term exchange rate volatility has a significant negative effect on global bovine meat trade while the long-term exchange rate volatility has a weak or no effect on trade flows. In bovine meat trade, the short-term volatility has a much larger effect than the long-term volatility as suggested by the size and significance of the elasticity coefficients. This finding is partially consistent with Cho et al. (2002), who suggested that both short and long-term exchange rate volatilities impair aggregate trade flows in sectorial trade.

In the global swine meat trade, the short-term volatility has no effect on the trade flows while there is evidence of a positive impact of long-term volatility on the flows. This study suggests that the impacts of exchange rate uncertainty is commodity-specific and may vary with computation methods. These findings show that the effects of exchange rate uncertainty are not uniform across commodities and models - a result that is consistent with Klein (1990).

\section{E. Meat differentiation based on country of origin}

Dummy variables representing major exporting countries are all significant at $1 \%$ level. The findings suggest that meat products are differentiated by country of origin. 
Further, the results suggest that exporting countries produce and export different types of meat products. However, meat quality differences by country of origin were not analyzed in this study. It may be a fruitful agenda for future research on meat product trade.

\section{Conclusion}

A commodity-specific gravity model was developed to evaluate factors affecting meat trade flows. This study demonstrated that the gravity models could be applied to single commodity trade flows such as bovine and swine meat trade flows. Particular attention was given to the effects of the world's major regional free trade agreements.

Income variables were significant factors influencing meat trade flows. Given that demand and supply are income-inelastic in trading countries, a sustained growth of the world economy would continue to stimulate meat trade. Per capita production and population were also significant factors influencing meat trade flows. Distances between trading countries were major factors reducing trade in meat. Common borders stimulated more trade.

The impacts of the world's major free trade agreements on bovine and swine meat trade were examined. The results showed that the formation of the North American Free Trade Agreement (NAFTA) and European Union (EU) significantly enhanced both bovine and swine meat trade flows through trade creation among members and trade diversion from non-members to members. The Common Market of the South (MERCOSUR) association led to trade creation with inconclusive results for trade diversion. The Association of South-East Asian Nations (ASEAN) led to trade diversion with no clear indication of trade creation among members. Hoof-and-mouth diseases impaired meat trade flows. The short-run exchange rate volatility significantly reduced bovine meat trade flows. There was evidence that long-term volatility had positive and significant effects on swine meat trade flows. Therefore, the impact of exchange rate uncertainty on meat trade flows was product-specific and may vary with the method of its computation. 


\section{References}

Anderson, James E, "A Theoretical Foundation for the Gravity Equation" American Economic Review (1979) 69 (1), p. 106-115.

Anderson, James E and Eric van Wincoop, "Gravity with Gravitas: A Solution to the Border Puzzle." American Economic Review (2003) 93, p. 170-192.

Bacchetta, Philippe, and Eric van Wincoop, "Does Exchange Rate Stability Increase Trade Welfare.?" American Economic Review (2000) 90 (5), p. 1093-1109.

Bergstrand, Jeffrey H., "The Gravity Equation in International Trade: Some Microeconomic Foundations and Empirical Evidence." Review of Economics and Statistics (1985) 67 (3), p. 474-481.

Bergstrand, Jeffrey H., "The Generalized Gravity Equation, Monopolistic Competition, and the Factor Proportions Theory in International Trade." Review of Economics and Statistics (1989), 71, p. 143-153.

Bergstrand, Jeffrey H, "The Heckscher-Ohlin-Samuelson Model, the Linder Hypothesis, and the Determinants of Bilateral Intra-Industry Trade." The Economic Journal (1990), 100 (403), p. 1216-1229.

Cao, Kay and Robin Johnson, "Impacts of Mandatory Meat Hygiene Regulations on the New Zealand Meat Trade.” Australasian Agribusiness Review (2006), Vol. 142006. http://www.agrifood.info/review/2006/Cao_Johnson.html, Accessed 11 27, (2012).

Cho, Guedae, Sheldon, M Ian and Steve McCorriston, "Exchange Rate Uncertainty and Agricultural Trade." American Journal of Agricultural Economics (2002), 84 (4), p. 931942.

Chowdhury, Abdur Rahman, "Does Exchange Rate Volatility Depress Trade Flows? Evidence From Error-Correction Models." The Review of Economics and Statistics (1993), 75 (4), p. 700-706.

Dascal, Dana, Mattas, Konstadinos and Vangelis Tzouvelekas, "An Analysis of EU Wine Trade: A Gravity Model Approach." International Advances in Economic Research (2002), 8(2), p. 137-43.

De Grauwe, De Paul and Frauke Skudelny, "The Impact of EMU on trade flows." Review of World Economics (2000), 140 (3), p.204-231. 
Egger, Peter, "Estimating Regional Trading Bloc Effects with Panel Data." Review of World Economics (2004), 14091, p151-166.

Estima, Inc. (2009), RATS User's Guide, 7, (p 246-247), Evanston, IL. FAOSTAT, (http://faostat3.fao.org/home/index.html), accessed May 27, (2014).

Hausman, Jerry A, "Specification tests in econometrics.” Econometrica (1978), 46 (6), p.1251-1271

Helpam, Elhanan, Marc Melitz and Yona Rubinstein, " Estimating Trade Flows: Trading Partners and Trading Volumes.” The Quarterly Journal of Economics (2008), 123(2), p441-487.

Hilbun, Brian Matthew, http://etd.1su.edu/docs/available/etd-04192006- 102931/ unrestricted/Hilbun_thesis.pdf: "An Analysis of Trade in Western hemisphere utilizing a Gravity Model Framework” (2006), accessed May 27, (2012).

Hsiao, Cheng, “Analysis of Panel Data.” New York: Cambridge University Press (1986) International Monetary Fund. International Financial Statistics, Various Issues. Washington, D.C: IMF. (http://www.imf.org/external/pubs/ft/weo/2012/01/weodata/ index.aspx), accessed on April 2012).

Jayasinghe, Sampath and Rakhal Sarker, "Effects of Regional Trade Agreements on Trade in Agrifood products: Evidence from Gravity Modeling using disaggregated data." Review of Agricultural Economics (2008), 30 (1), p. 61-81.

Judge, George G, Griffiths, William E, Carter Hill R, Helmut Lutkepohl and Lee Tsoung-Chao (1985), The Theory and Practice of Econometrics $\left(2^{\text {nd }}\right)$. New York: John Wiley and Sons.

Karemera, David, Managi, Shunsuke, Reuben Lucy and Ora Spann, " The Impact of Exchange Rate Volatility on Vegetable Trade Flows." Applied Economics (2011), Vol. 41, p. 1607-1616.

Karemera, David, Paul Rienstra-Munnicha and Joseph Onyeocha, "Free Trade Effects of NAFTA and the Impact of Exchange Rate Volatility on Vegetable \& Fruit Trade Flows", Journal of Economics Integration (2009), 24 (1), p. 116-134.

Karemera, David, Kalu Ojah, Wilbur Smith, and John A Cole, "A Gravity Model Analysis of the Benefits of Economics Integration in the Pacific Rim". Journal of 
Economic Integration (1999), 14 (3), p. 347-367.

Klein, Michael W., "Sectorial Effects of Exchange Rate Volatility on United States Exports." Journal of International Money and Finance (1990), 9 (3), p. 299-308.

Koo Won. Whom; Karemera, David and Richard. Taylor, “A Gravity Model Analysis of Meat Trade Policies.” Agricultural Economics (1993), 10 (1), p. 81-88.

Koray, Faik and William D. Lastrapes, "Real Exchange Rate Volatility and U.S. Bilateral Trade: A Var Approach.” The Review of Economics and Statistics (1989), 71 (4), p. 708-712.

Langley, Suchada V., Marcelo Guigale, William H. Meyers and Charles Hallahan, "International Financial Volatility and Agricultural Commodity Trade: A Primer." American Journal of Agricultural Economics (2000), 82 (3), p. 695-700.

Linneman, Hans, An Econometric Study of International Trade Flows, Amsterdam: North Holland Publishing, 1966

Martinez-Zarzoso, Inmaculata, Nowak-Lehman Felicitas and Nicholas Horsewood, "Are Regional Trading Agreements Beneficial? Static and Dynamic Panel Gravity Models." The North American Journal of Economics and Finance (2009), 20(1), p1-23.

Pagoulatos, Emilio and Robert Sorensen, "Two-Way International Trade: An Econometric Analysis.” Weltwirtschaftliches Archiv (1975), 111, p. 454-465.

Peree, Erica and Alfred Steinherr, "Exchange Rate Uncertainty and Foreign Trade", European Economic Review (1989), 33: p. 1241-1264.

Pick, Daniel H, "Exchange Rate Risk and U.S. Agricultural Trade Flows." American Journal of Agricultural Economics (1990), 72 (3), p. 94-700.

Time Atlas of Ocean, Time Book Limited, in various issues.

World Economic Outlook Database April 2012, various issues, accessed October 2012 (http:/www.imf.org/external/pubs/ft/weo/2012/01/weodata/index.aspx.

Zhou, Zhangyue et al. "Food Consumption Trends in China", Australian Government Department of Agriculture, Fisheries and Forestry (2012) 
Table 3. The Eicker-White Heteroscedasticity-consistent estimates of a gravity model of bovine meat

\begin{tabular}{|c|c|c|c|c|c|c|c|c|}
\hline \multirow{3}{*}{ Variables } & \multicolumn{4}{|c|}{ Eicker-White Consistent Estimator } & \multicolumn{4}{|c|}{ OLS } \\
\hline & \multicolumn{2}{|c|}{ Short-term Volatility } & \multicolumn{2}{|c|}{ Long-term Volatility } & \multicolumn{2}{|c|}{ Short-term Volatility } & \multicolumn{2}{|c|}{ Long-term Volatilit } \\
\hline & Coef & T-Score & Coef & T-Score & Coef & T-Score & Coef & T-Score \\
\hline Constant & -0.16 & $(-0.15)$ & -0.94 & $(-1.37)$ & -0.16 & $(-0.15)$ & -0.92 & $(-1.37)$ \\
\hline$H M D$ & $-0.71 * * *$ & $(-10.25)$ & $-0.65^{* * *}$ & $(11.55)$ & $-0.71 * * *$ & $(-10.57)$ & $-0.65^{* * *}$ & $(-11.55)$ \\
\hline Exports Per Capita GDP & $0.10^{* * *}$ & $(3.55)$ & $0.08^{* * *}$ & (4.46) & $0.10^{* * *}$ & $(3.71)$ & $0.08^{* * *}$ & (4.46) \\
\hline Imports Per Capita GDP & $0.11 * * *$ & $(5.16)$ & $0.10^{* * *}$ & (7.67) & $0.11^{* * *}$ & $(5.63)$ & $0.10^{* * *}$ & $(7.67)$ \\
\hline Exporter's Population & $0.16^{* * *}$ & (7.89) & $0.14 * * *$ & $(9.94)$ & $0.16^{* * *}$ & $(8.55)$ & $0.14^{* * *}$ & $(9.94)$ \\
\hline Importers Population & $0.19^{* * *}$ & $(12.22)$ & $0.16^{* * *}$ & $(13.75)$ & $0.19^{* * *}$ & $(13.75)$ & $0.16^{* * *}$ & $(13.75)$ \\
\hline Distance & $-0.23^{* * *}$ & $(-11.29)$ & $-0.25^{* * *}$ & $(-14.94)$ & $-0.23^{* * *}$ & $(-10.4)$ & $-0.25^{* * *}$ & $(-14.94)$ \\
\hline Exporter's Livestock Production & 0.16 & $(1.27)$ & $0.34 * * *$ & (4.49) & 0.16 & $(1.22)$ & $0.34^{* * *}$ & $(4.49)$ \\
\hline Importer's Livestock Production & -0.1 & $(-1.44)$ & 0.01 & $(0.19)$ & -0.14 & $(-1.28)$ & 0.012 & $(0.19)$ \\
\hline Both Countries EU & $2.7^{* * *}$ & (40.94) & $3.07 * * *$ & (52.97) & $2.7^{* * *}$ & $(34.92)$ & $3.07^{* * *}$ & $(52.97$ \\
\hline One Country EU & $-0.59^{* * *}$ & $(-10.48)$ & $-0.43^{* * *}$ & $(-10.32)$ & $-0.59 * * *$ & $(-10.85)$ & $-0.43 * * *$ & $(-10.32)$ \\
\hline Both Countries MERCOSUR & $1.63^{* * *}$ & $(9.75)$ & $1.80 * * *$ & $(11.43)$ & $1.63^{* * *}$ & $(7.32)$ & $1.80^{* * *}$ & $(11.43)$ \\
\hline One Country MERCOSUR & $1.88^{* * *}$ & $(25.72)$ & $1.60^{* * *}$ & $(28.39)$ & $1.88^{* * *}$ & $(24.58)$ & $1.60^{* * *}$ & $(28.39)$ \\
\hline Both Countries ASEAN & $-0.94 * * *$ & $(-4.93)$ & $-0.73^{* * *}$ & $(-5.27)$ & $-0.94 * * *$ & $(-4.69)$ & $-0.73 * * *$ & $(-5.27)$ \\
\hline One Country ASEAN & $-0.18^{* *}$ & $(-2.12)$ & $-0.39^{* * *}$ & $(-6.44)$ & $-0.18^{* *}$ & $(-2.3)$ & $-0.39^{* * *}$ & $(-6.44)$ \\
\hline Both Countries NAFTA & $2.48^{* * *}$ & $(6.49)$ & $1.76^{* * *}$ & $(5.18)$ & $2.48 * *$ & $(6.24)$ & $1.76^{* * *}$ & $(5.18)$ \\
\hline One Country NAFTA & -0.03 & $(-0.21)$ & $-0.38^{* * *}$ & $(-3.6)$ & -0.03 & $(-0.25)$ & $-0.38^{* * *}$ & $(-3.6)$ \\
\hline Share a Common Land Border & $1.23^{* * *}$ & $(14.12)$ & $1.31 * * *$ & $(17.02)$ & $1.23 * * *$ & $(11.71)$ & $1.31 * * *$ & $(17.02)$ \\
\hline Exchange Rate Volatility & $-0.46^{* * *}$ & $(-3.6)$ & 0.023 & $(0.86)$ & $-0.46^{* * *}$ & $(-3.55)$ & 0.023 & $(0.86)$ \\
\hline Australia & $0.95^{* * *}$ & $(8.66)$ & $0.91 * * *$ & $(9.84)$ & $0.95^{* * *}$ & $(9.88)$ & $0.91 * * *$ & $(9.84)$ \\
\hline Brazil & $0.55^{* * *}$ & $(5.41)$ & $0.54 * * *$ & $(6.09)$ & $0.55^{* * *}$ & $(5.25)$ & $0.54 * * *$ & $(6.09)$ \\
\hline Netherlands & $0.80^{* * *}$ & $(11.31)$ & $0.90 * * *$ & $(15.49)$ & $0.80^{* * *}$ & $(10.37)$ & $0.90^{* * *}$ & $(15.49)$ \\
\hline$U S$ & $0.30^{*}$ & (1.74) & $0.84 * * *$ & $(6.55)$ & $0.30^{* *}$ & $(1.97)$ & $0.84 * * *$ & $(6.55)$ \\
\hline Germany & $0.28 * * *$ & $(3.32)$ & $0.58^{* * *}$ & $(8.15)$ & $0.28^{* * *}$ & $(3.12)$ & $0.58^{* * *}$ & $(8.15)$ \\
\hline France & $0.44 * * *$ & (6.35) & $0.56 * * *$ & $(9.25)$ & $0.44^{* * *}$ & (5.57) & 0.56 *** & $(9.25)$ \\
\hline \multicolumn{9}{|l|}{ Statistics } \\
\hline $\mathrm{N}$ & \multicolumn{2}{|c|}{11,048} & \multicolumn{2}{|c|}{20,519} & \multicolumn{2}{|c|}{11,048} & \multicolumn{2}{|c|}{20,519} \\
\hline $\mathrm{R}^{2}$ & \multicolumn{2}{|c|}{0.341} & \multicolumn{2}{|c|}{0.303} & \multicolumn{2}{|c|}{0.341} & \multicolumn{2}{|c|}{0.303} \\
\hline SEE & \multicolumn{2}{|c|}{2.229} & \multicolumn{2}{|c|}{2.37} & \multicolumn{2}{|c|}{2.229} & \multicolumn{2}{|c|}{2.37} \\
\hline Log Likelihood & \multicolumn{2}{|c|}{$-24,518.648$} & \multicolumn{2}{|c|}{$-46,804.886$} & \multicolumn{2}{|c|}{237.252} & \multicolumn{2}{|c|}{370.501} \\
\hline
\end{tabular}

(Note) $* * *$ denotes statistically significance at the $1 \%$ level,

$* *$ denotes statistically significance at the $5 \%$ level,

*denotes statistically significance at the $10 \%$ level. 
Table 4. The Eicker-White Heteroscedasticity-consistent estimates of a gravity model of swine meat

\begin{tabular}{|c|c|c|c|c|c|c|c|c|}
\hline \multirow{3}{*}{ Variables } & \multicolumn{4}{|c|}{ Eicker-White Consistent Estimator } & \multicolumn{4}{|c|}{ OLS } \\
\hline & \multicolumn{2}{|c|}{ Short-term Volatility } & \multicolumn{2}{|c|}{ Long-term Volatility } & \multicolumn{2}{|c|}{ Short-term Volatility } & \multicolumn{2}{|c|}{ Long-term Volatility } \\
\hline & Coef & T-Score & Coef & T-Score & Coef & T-Score & Coef & T-Score \\
\hline Constant & $-8.63^{* * *}$ & $(-3.8)$ & $-6.26^{* * *}$ & $(-4.84)$ & $8.63 * * *$ & $(-3.79)$ & $-6.26^{* * *}$ & $(-4.75)$ \\
\hline Exporters Per Capita GDP & $0.32^{* * *}$ & $(5.79)$ & $0.16^{* * *}$ & $(4.77)$ & $0.32 * * *$ & $(5.97)$ & $0.16^{* * *}$ & $(4.87)$ \\
\hline Importer's Per Capita GDP & $0.382^{* * *}$ & $(9.72)$ & $0.18^{* * *}$ & $(8.33)$ & $0.38^{* * *}$ & $(9.95)$ & $0.18^{* * *}$ & $(8.4)$ \\
\hline Exporter's Population & $0.16^{* * *}$ & $(4.15)$ & $0.13 * * *$ & $(5.16)$ & $0.16^{* * *}$ & $(4.12)$ & $0.13^{* * *}$ & $(5.23)$ \\
\hline Importers Population & $0.25^{* * *}$ & $(8.46)$ & $0.20 * * *$ & $(9.94)$ & $0.245^{* * *}$ & $(8.33)$ & $0.20^{* * *}$ & $(9.74)$ \\
\hline Distance & $-0.38^{* * *}$ & $(-10.75)$ & $-0.43^{* * *}$ & $(-15.39)$ & $-0.376^{* * *}$ & $(-10.13)$ & $-0.43^{* * *}$ & $(-15.14)$ \\
\hline Exporter's Livestock Production & $0.47^{*}$ & $(1.67)$ & $0.52^{* * *}$ & $(3.36)$ & $0.472^{*}$ & $(1.77)$ & $0.52^{* * *}$ & $(3.49)$ \\
\hline Importer's Livestock Production & 0.39 & $(1.6)$ & $0.79^{* * *}$ & $(6.19)$ & 0.389 & $(1.62)$ & $0.79^{* * *}$ & $(6.01)$ \\
\hline Both Countries EU & $0.94 * * *$ & $(8.67)$ & $1.50^{* * *}$ & $(16.55)$ & $0.942 * * *$ & $(8.19)$ & $1.50^{* * *}$ & $(16.04)$ \\
\hline One Country EU & $-1.51 * *$ & $(-13.69)$ & $-1.28^{* * *}$ & $(-17.82)$ & $-1.505^{* * *}$ & $(-14.13)$ & $-1.28 * *$ & $(-17.71)$ \\
\hline Both Countries MERCOSUR & $-1.41 * *$ & $(-3.54)$ & $-1.84^{* * *}$ & $(-5.36)$ & $-1.411 * * *$ & $(-2.86)$ & $-1.84 * *$ & $(-4.97)$ \\
\hline One Country MERCOSUR & 0.23 & $(1.1)$ & $-0.22^{*}$ & $(-1.65)$ & 0.232 & $(0.91)$ & -0.22 & $(-1.53)$ \\
\hline Both Countries ASEAN & $-3.11 * * *$ & $(-8.21)$ & $-3.00^{* * *}$ & $(-11.19)$ & $-3.109^{* * *}$ & $(-5.93)$ & $-3.00^{* * *}$ & $(-8.93)$ \\
\hline One Country ASEAN & $-0.74 * * *$ & $(-4.1)$ & $-0.71^{* * *}$ & $(-6.41)$ & $-0.74 * * *$ & $(-4.82)$ & $-0.71 * *$ & $(-6.75)$ \\
\hline Both Countries NAFTA & $3.18^{* * *}$ & $(9.59)$ & $2.67^{* * *}$ & $(5.11)$ & $3.178^{* * *}$ & $(5.22)$ & $2.67^{* * *}$ & $(5.77)$ \\
\hline One Country NAFTA & $0.47^{* * *}$ & (3.3) & $0.51^{* * *}$ & $(4.99)$ & $0.466^{* * *}$ & $(3.11)$ & $0.51^{* * *}$ & $(4.83)$ \\
\hline Share a Common Land Border & $1.09^{* * *}$ & $(7.44)$ & $1.2^{* * *}$ & $(9.58)$ & $1.087^{* * *}$ & $(6.55)$ & $1.23^{* * *}$ & $(8.92)$ \\
\hline Exchange Rate Volatility & -0.06 & $(-0.16)$ & $0.012^{* * *}$ & $(2.66)$ & -0.061 & $(-0.15)$ & $0.011^{* *}$ & $(2.25)$ \\
\hline Japan & 0.22 & $(0.9)$ & $0.79 * * *$ & $(4.05)$ & 0.224 & $(1.13)$ & $0.79 * * *$ & $(5.18)$ \\
\hline Denmark & $2.11^{* * *}$ & $(16.68)$ & $2.13^{* * *}$ & $(20.81)$ & $2.11^{* * *}$ & (16.1) & $2.13 * * *$ & $(20.89)$ \\
\hline Germany & $1.10^{* * * *}$ & $(7.59)$ & $0.77^{* * *}$ & $(6.47)$ & $1.104^{* * *}$ & $(7.35)$ & $0.77 * * *$ & $(6.65)$ \\
\hline Mexico & $-0.92^{* *}$ & $(-2.20)$ & -0.51 & $(-1.42)$ & $-0.922^{*}$ & $(-1.96)$ & -0.51 & $(-1.62)$ \\
\hline United Kingdom & $-0.93 * *$ & $(-2.00)$ & $-0.77^{* *}$ & $(-2.49)$ & -0.933 & $(-1.55)$ & $-0.77^{*}$ & $(-2.12)$ \\
\hline$U S$ & $-1.56 * * *$ & $(-4.66)$ & $-1.81 * *$ & $(-7.53)$ & $-1.562 * *$ & $(-2.15)$ & $-1.81 * * *$ & $(-3.5)$ \\
\hline Netherlands & $0.82 * * *$ & $(6.02)$ & $0.86^{* * *}$ & (8.2) & $0.815^{* * *}$ & (6.31) & $0.86^{* * *}$ & (8.54) \\
\hline Italy & $0.33^{* * *}$ & $(2.81)$ & $0.38^{* * *}$ & (3.9) & $0.329^{* *}$ & $(2.57)$ & $0.38^{* * *}$ & (3.62) \\
\hline \multicolumn{9}{|l|}{ Statistics } \\
\hline $\mathrm{N}$ & \multicolumn{2}{|c|}{3,377} & \multicolumn{2}{|c|}{6,724} & \multicolumn{2}{|c|}{3,377} & \multicolumn{2}{|c|}{6,724} \\
\hline $\mathrm{R}^{2}$ & \multicolumn{2}{|c|}{0.412} & \multicolumn{2}{|c|}{0.371} & \multicolumn{2}{|c|}{0.412} & \multicolumn{2}{|c|}{0.371} \\
\hline SEE & \multicolumn{2}{|c|}{2.236} & \multicolumn{2}{|c|}{2.34} & \multicolumn{2}{|c|}{2.236} & \multicolumn{2}{|c|}{2.34} \\
\hline Log Likelihood & \multicolumn{2}{|c|}{$-7,496.448$} & \multicolumn{2}{|c|}{$-15,244.904$} & \multicolumn{2}{|c|}{94.082} & \multicolumn{2}{|c|}{158.034} \\
\hline
\end{tabular}

(Notes) (i) T-ratios are in parentheses under corresponding estimates.

(ii) $* * *$ denotes statistically significance at the $1 \%$ level,

$* *$ denotes statistically significance at the $5 \%$ level,

*denotes statistically significance at the $10 \%$ level. 
Table 5. Countries studied for the bovine and swine meat trade

\section{A. Bovine meat trading countries}

\section{Exporting/Importing Countries}

\begin{tabular}{|l|l|l|}
\hline Argentina & Australia & Austria \\
\hline Belgium & Belgium-Luxembourg & Brazil \\
\hline Bulgaria & Canada & Chile \\
\hline China & China, Hong Kong SAR & China, Macao SAR \\
\hline Croatia & Cuba & Czech Republic \\
\hline Denmark & Estonia & Finland \\
\hline France & Germany & Greece \\
\hline Hungary & Indonesia & Ireland \\
\hline Italy & Japan & Lithuania \\
\hline Luxembourg & Malaysia & Namibia \\
\hline Netherlands & New Zealand & Papua New Guinea \\
\hline Paraguay & Philippines & Poland \\
\hline Portugal & Qatar & Romania \\
\hline Russian Federation & Saudi Arabia & Serbia and Montenegro \\
\hline Seychelles & Singapore & Slovakia \\
\hline Slovenia & South Africa & Spain \\
\hline Sweden & Switzerland & Trinidad and Tobago \\
\hline United Arab Emirates & United Kingdom & \\
\hline Vanuatu & & \\
\hline & & Untes of America \\
\hline
\end{tabular}

\section{Importing Only Countries}

Guinea

Maldives 


\section{B. Swine meat trading countries}

\section{Exporting/ Importing countries}

\begin{tabular}{|l|l|l|}
\hline Argentina & Australia & Austria \\
\hline Belgium & Belgium-Luxembourg & Brazil \\
\hline Bulgaria & Canada & Chile \\
\hline China & China, Hong Kong SAR & China, Macao SAR \\
\hline Croatia & Cuba & Czech Republic \\
\hline Denmark & Estonia & Finland \\
\hline France & Germany & Greece \\
\hline Hungary & Indonesia & Ireland \\
\hline Italy & Japan & Lithuania \\
\hline Luxembourg & Malaysia & Namibia \\
\hline Netherlands & New Zealand & Papua New Guinea \\
\hline Paraguay & Philippines & Poland \\
\hline Portugal & Qatar & Romania \\
\hline Russian Federation & Serbia and Montenegro & Seychelles \\
\hline Singapore & Slovakia & Slovenia \\
\hline South Africa & Spain & Sweden \\
\hline Switzerland & Trinidad and Tobago & United Arab Emirates \\
\hline United Kingdom & United States of America & \\
\hline
\end{tabular}

\section{Importing only Countries}

\begin{tabular}{|l|l|l|}
\hline Guinea & Maldives & Vanuatu \\
\hline
\end{tabular}




\section{Table 6. Free trade blocs and member countries}

\begin{tabular}{|c|c|c|c|}
\hline Canada & Mexico & United States of America & \\
\hline \multicolumn{4}{|c|}{ 2. EU Countries } \\
\hline Austria & Belgium & Belgium-Luxembourg & Bulgaria \\
\hline Cyprus & Czech Republic & Denmark & Estonia \\
\hline Finland & France & Germany & Greece \\
\hline Hungary & Ireland & Italy & Latvia \\
\hline Lithuania & Luxembourg & Malta & Netherlands \\
\hline Poland & Portugal & Romania & Slovakia \\
\hline Slovenia & Spain & Sweden & United Kingdom \\
\hline \multicolumn{4}{|c|}{ 3. ASEAN Countries } \\
\hline Brunei & Cambodia & Indonesia & Laos \\
\hline Malaysia & Myanmar & Philippines & Singapore \\
\hline Thailand & Vietnam & & \\
\hline \multicolumn{4}{|c|}{ 4. MERCOSUR Countries } \\
\hline Argentina & Brazil & Paraguay & Uruguay \\
\hline
\end{tabular}

